\title{
A Hebrew Poet Writes in English about the Holocaust
}

\author{
Avraham Balaban \\ University of Florida
}

Follow this and additional works at: https://docs.lib.purdue.edu/clcweb

(3)

Part of the Comparative Literature Commons

Dedicated to the dissemination of scholarly and professional information, Purdue University Press selects, develops, and distributes quality resources in several key subject areas for which its parent university is famous, including business, technology, health, veterinary medicine, and other selected disciplines in the humanities and sciences.

CLCWeb: Comparative Literature and Culture, the peer-reviewed, full-text, and open-access learned journal in the humanities and social sciences, publishes new scholarship following tenets of the discipline of comparative literature and the field of cultural studies designated as "comparative cultural studies." Publications in the journal are indexed in the Annual Bibliography of English Language and Literature (Chadwyck-Healey), the Arts and Humanities Citation Index (Thomson Reuters ISI), the Humanities Index (Wilson), Humanities International Complete (EBSCO), the International Bibliography of the Modern Language Association of America, and Scopus (Elsevier). The journal is affiliated with the Purdue University Press monograph series of Books in Comparative Cultural Studies. Contact: <clcweb@purdue.edu>

\section{Recommended Citation}

Balaban, Avraham. "A Hebrew Poet Writes in English about the Holocaust." CLCWeb: Comparative Literature and Culture 22.1 (): <https://doi.org/10.7771/1481-4374.3717>

The above text, published by Purdue University Press @P Purdue University, has been downloaded 0 times as of $04 / 28 /$ 20.

This document has been made available through Purdue e-Pubs, a service of the Purdue University Libraries. Please contact epubs@purdue.edu for additional information.

This is an Open Access journal. This means that it uses a funding model that does not charge readers or their institutions for access. Readers may freely read, download, copy, distribute, print, search, or link to the full texts of articles. This journal is covered under the CC BY-NC-ND license. 


\section{PURDUE}

UNIVERSITY PRESS <http://www.thepress.purdue.edu>

\section{CLCWeb: Comparative Literature and Culture}

ISSN 1481-4374 <http://docs.lib.purdue.edu/clcweb> Purdue University Press @Purdue University

CLCWeb: Comparative Literature and Culture, the peer-reviewed, full-text, and open-access learned journal in the humanities and social sciences, publishes new scholarship following tenets of the discipline of comparative literature and the field of cultural studies designated as "comparative cultural studies." In addition to the publication of articles, the journal publishes review articles of scholarly books and publishes research material in its Library Series. Publications in the journal are indexed in the Annual Bibliography of English Language and Literature (ChadwyckHealey), the Arts and Humanities Citation Index (Thomson Reuters ISI), the Humanities Index (Wilson), Humanities International Complete (EBSCO), the International Bibliography of the Modern Language Association of America, and Scopus (Elsevier). The journal is affiliated with the Purdue University Press monograph series of Books in Comparative Cultural Studies. Contact: <clcweb@purdue.edu>

\section{FreeWrite}

Volume 22 Issue 1 (March 2020) Article 11 Avraham Balaban,

"A Hebrew Poet Writes in English about the Holocaust"

<http://docs.lib.purdue.edu/clcweb/vol22/iss1/11>

Contents of CLCWeb: Comparative Literature and Culture 22.1 (2020)

Special Issue Poetry in Israel: Forging Identity. Ed. Chanita Goodblatt

$<$ http://docs.lib.purdue.edu/clcweb/vol22/iss1/> 


\section{Avraham BALABAN}

\section{A Hebrew Poet Writes in English about the Holocaust}

In the early 1990s I was teaching at the University of Florida. My family lived in Israel, and I would fly to Florida for the school year and then return to Israel for the summer vacation. I lived in Gainesville in a rented apartment, in an apartment complex in the northern part of the city, and once or twice a week I would wash my clothes in the complex's laundromat. I clearly remember one particular Saturday: I lifted the lid of the dryer and the jumble of clothes reminded me of a pile of twisted corpses. A few days earlier I had called my mother, who lived on Kibbutz Huldah; it was the traditional phone call for the Israeli Holocaust Remembrance Day. We had a conversation that would be unintelligible for anyone except for my mother and myself. As usual in this phone call, my mother would mainly remain silent. I remembered hearing her sorrowful voice as she told me in my childhood about the fate of her family in Bessarabia: about her father who managed an oil factory, about her sister who was with her in a training camp for Zionist pioneers in Romania, and instead of immigrating to Palestine decided to go back home to say goodbye to her parents and disappeared with them, and about her brother Pinchas (Pinkele) who was found shot in a field gripping a head of cabbage. I recognized these family members only from blurred black and white photos that my mother kept in a wooden box. I tried to chronicle these stories, that were told to me in my youth, in one of my first poems that was published in Hapo'el Hatsa'ir (The Young worker) Newspaper, when I was sixteen years old.

I should add that as children growing up in a Kibbutz during the 1940s and 1950s, we did not share a sense of solidarity with the annihilated European Jewry. Our parents were Zionist "pioneers" who had rebelled against their parents and the identity of the Diaspora Jew, and they strove to raise us so that we would be, as much as possible, different from the Jews of the East European towns from which they came: tanned, upright, independent, courageous. As a young child in pre-school, I was fascinated by my parents' Yiddish, but when I asked my father to teach me the language, he stubbornly refused. Yiddish was identified with the Diaspora. There were two cracks in this cultural wall of arrogance and disdain that separated our lives from those lived in Europe. First, my mother, who came to Palestine in March 1938 from Bessarabia, and lost her entire family in the Holocaust, except one brother, frequently showed me photographs of her family. Somehow, I did not identify these members as part of an entire community of Jews that perished "over there." Secondly, when I was in my first years of primary school, our teachers showed us a short film made by American soldiers in the Concentration Camps. These pictures of bony corpses, piled up one over the other, haunted me for many months.

Aside from the poem in which I tried to capture this scene of my mother telling me about her family, I had never written anything else about the Holocaust until that Saturday in Gainesville. I did not include this early poem in any of my published books of poems. A year before this episode with the laundry, I had begun to assemble material about the Holocaust, with the goal of writing a novel about my mother's family. Perhaps living alone in Florida, without the support of family or friends, intensified the impact of the documents I had gathered and the movies I had seen. When cleaning up pots and pans after dinner in my Gainesville kitchen began to remind me of the cleaning out of corpses from the gas chambers, I realized that if I wanted to keep my sanity intact, this subject matter should remain unapproached, at least while living alone in a foreign country.

Back to this same Saturday and the picture that went through my mind as I saw the pile of dried clothes. I came back with my clothes from the laundromat to my rented apartment and left them on the couch. I sat in front of my computer and began writing a poem. Until then, I had published three books of poetry in Hebrew. Even though I had already lived in the U.S. for seven years, it never occurred to me to write poetry in English. I was familiar with English poetry, mainly 20th century poets (Yeats, Eliot, Pound, Auden and their generation of poets), and of course was an avid reader of English literature. Yet the language remained foreign and distant. Whenever I taught Hebrew poetry at the University of Florida, I thought about the significant difference between the Hebrew word and its English counterpart. The Hebrew word איקליפוּו a wealth of senses (smells, the touch of dried leaves on my bare feet). Conversely, the English word that designates this same tree, "Eucaplyptus," remains for me alien, sterile, like a scientific illustration in a schoolbook.

With the piles of dried clothes lying on the couch, I sat down and attempted to write a poem. At the end of the evening, I added a few explanatory lines, explaining to the possible reader to whom I was dedicating the poem. To my surprise, the first lines were written in English. I did not stop to understand why. Only in retrospect did I understand: it was the foreignness and the sterility of the English language, which enabled me to achieve the necessary distance in order to cope (alone, in a foreign city) with the 
unbearable image of a pile of corpses in the laundry room. Interestingly enough, without even noticing, I had written the poem in the third person, as if to further create a safe distance from this image:

Family Reunion

In memory of my mother's parents and their children who were marched by the Nazis in the dead of winter to Transnistria where they died of starvation and plagues.

Opening the dryer door

once again he sees

the medley of sleeves and

pants and socks-

a pile of embracing bodies, twisted.

And once again he cannot escape his mother's voice,

pointing to the black and white pictures:

Grandfather Avraham, Grandmother Ita

Leah, Pinkele, Sarale.

The sweat on his back is a scar of frost.

Gently he sorts out his clothes,

still warm against his chest.

Gainesville, Florida.

A lonely man quietly

walks out, surprised by

a bright spring day.

Until next weekend,

until his next reunion,

his family is never far

from his closet.

[Or: may he have some rest]

This poem, which was written more than a quarter of a century ago, remained unfinished. Whenever I write a poem in Hebrew, I know exactly when the work is completed. I know exactly when the poem's components, its images and rhythm and sound, are compatible with its ending. This poem remained unfinished in various ways. First, it concluded with two instances of closure. Among other things, I was not sure whether the line "his family is never far from his closet" would insinuate that "he had skeletons in his closet." Also, I was not sure whether or not "may he have some rest" is too sentimental. More crucially, I wrote something that had some qualities I could not fully appreciate. Whenever I write in Hebrew, I can use the rhythm and sounds to intensify significant elements such as tone and atmosphere, or strive to emphasize certain words. My use of the English language does not provide me with this ability and the whole poem is based on its central image. Does this specific image in its literal form convey the same uneasiness and horrified sentiments I felt? I honestly do not know. Whenever I finish writing a poem, there is this irresistible urge to publish it as soon as possible. That particular poem was immediately sent to my desk drawer (or to a remote file in my computer). I had never planned to publish it.

Ten years later, when I taught for several terms at Cambridge, I went to Rome with my wife. We visited the Jewish Ghetto, and that particular afternoon we also arrived at the famous market, Campo di Fiori. After 3:00 P.M., the peddlers began to collect their merchandise and bring it to a small square nearby. The boxes of apples and flowers were carried in what seemed to me to be stretchers: a long wooden board on two iron wheels. From these carriages I suddenly saw dead pale hands dragging along on the asphalt pavement. Upon returning to Cambridge, I tried to depict this image in a poem. And once more, without asking myself why, I began writing in English. Only in retrospect did I understand that, without noticing it, I preferred once more to create a safe distance between this picture and myself.

European Travel, Summer 2001

The narrow streets of the old Jewish ghetto of Rome

broaden a little,

making way for a piazza surrounded by cafes,

pizzerias, red-and-yellow pennants of a local soccer team.

The voices of vegetable and flower vendors do not disturb

the peace of Giordano Bruno,

who surveys the commotion from the pedestal of his blackened statue. 
At three o'clock, a nearby vendor begins to load apple crates

onto a flat iron cart:

two big wheels and large handles, like a stretcher's.

More and more carts emerge

out of the fruit crates hauled into a warehouse.

A pair of pale legs slides to the ground.

Scrawny hands slither from among bouquets of roses.

The translucent palms

tap on the piazza stones

to the rhythm of the vendors' steps.

Once more, I found myself writing an unfinished poem. My English had improved in the decade since "Family Reunion" (at that time I was the Chair of the Department of African and Asian Languages and Literatures at the University of Florida). Yet it still remained a foreign language for me. After fifteen years in the U.S. I could sense that the language in the poem was clumsy and unrefined, but I could not mend this.

The only poem I wrote in English that was published in an American journal was a short poem written after reading a printed notice that had been posted on the door of Grinter Building, which housed the campus offices. It was a notice forbidding people from bringing dogs into the building, and was printed on yellow paper. This yellow notice reminded me of German signs forbidding Jews from entering businesses and other institutions.

\section{No Dogs Allowed}

A yellow printed note at the entrance

of Grinter Hall:

No Dogs Allowed.

And every morning,

entering the building

on my way to my office,

a vague click crosses me once-

like an alarm-clock's hand

passing over the hour on which once

it used to ring.

Why did I feel that this poem was complete? Perhaps because it was short and I felt that I was more in control of the relation between image and rhythm. Yet it still remained unclear, for example, whether it worked better without the repetition of the word "once."

I am fully aware of writers who immigrated to other countries, and were able to adapt themselves to a new language. But they were novelists, not poets, who were already acquainted at a young age with the language in which they eventually became famous (Nabokov grew up in an Anglophile family, learned English from young age and was already at the age of 20 a student at Cambridge; Joseph Conrad was born in Poland, but moved to Switzerland when he was 11). I came to America when I was 40, without any prior experience in English. I did not find it difficult to chair a department in the University, or to publish my research in English. Yet as far as poetry was concerned, outside the familiar territory of the Hebrew language, I felt like a fish out of water. It seems to me that for those who grew up as I did in Israel during the 1940s, Hebrew was burnt on us like a mark branded on a cow's hide.

Author's profile: Avraham Balaban is Professor Emeritus of Modern Hebrew Literature at the University of Florida. He has published four books of poetry in Hebrew (the latest is Poetry in a Foreign City), two novels in Hebrew, a literary memoir Mourning published both in Hebrew and English, and eight scholarly books in Hebrew (the latest is Mothers and Motherhood in Modern Hebrew Fiction). Email: <avraham.balaban@gmail.com> 